\title{
INVESTIGATION OF A NON-THERMAL EFFECT OF MICROWAVE TREATMENT
}

\author{
V. KapCSÁNDI, A.J. KovÁcs, M. NemÉnyi and E. LaKatos* \\ Institute of Biosystems Engineering, Faculty of Agricultural and Food Sciences, University of West Hungary, \\ H-9200 Mosonmagyaróvár, Vár u. 2. Hungary
}

(Received: 18 August 2014; accepted: 3 June 2015)

\begin{abstract}
The aim of our experiments was to demonstrate the non-thermal effect of microwave treatment on Saccharomyces cerevisiae fermentation activity. A method was developed for studying the effects of various treatments in the course of must fermentation. The raw material (must) was treated in different ways: (i) heat transfer; (ii) microwave treatment; (iii) inoculation with yeast, and (iv) their combinations. The results of the treatments were compared with respect to alcohol concentration, sugar content, and acidity. The results proved that sugar content of the treated samples rapidly decreased compared to the control sample, and fermentation time was $40 \%$ shorter in the fastest case. These results can be explained by the yeast inoculation and microwave treatment. Due to non-thermal effects, fermentation capacity increased by about $30 \%$, while the energy consumption decreased.
\end{abstract}

Keywords: microwave radiation, non-thermal effect, Saccharomyces cerevisiae, grape must, fermentation

The application and presence of different species of microorganisms (bacterium, yeasts, and filamentous fungi) are well known during the production of alcoholic beverages (FARKAS et al., 2005). The role of yeasts in wine making (e.g. wine yeast S. cerevisiae) is different, but they are important in the development of taste and aroma (PRETORIUS, 2000).

The main task of winemaking technology is to optimize the fermentation process in order to reach suitable production of wine (EPERJESI et al., 1998). Complex processes are taking place simultaneously during the fermentation of must, which could influence the process in different ways. During fermentation the emphasis is mostly to optimize the alcohol, sugar, and acid contents (PiCKERING et al., 1998; BiACs et al., 2010). However, controlled fermentation is a well-regulated process with the correct application necessary for influencing parameters (CALAdo et al., 2002; SABlayrolles, 2009). The effect of fermentation activity can be reduced by heat treatment (microwave heat treatment, heat treated with water-bath) (GÉcZi et al., 2013; KorZENSZKy \& MolnÁR, 2014a,b) and so on.

It is evident that microwaves (MW) cause different biological effects depending on field strength, frequencies, wave forms, modulation, and duration of exposure (RAI et al., 1994a,b). There has been considerable controversy over the non-thermal effect of MW radiation (Wayland et al., 1977; Dreyfuss \& Chipley, 1980; Welt et al., 1994; Kothari et al., 2011; TRIVEDI et al., 2011). Our aim was to back up the non-thermal effects of MW, based on i.a. the work of SHU-WEI and co-workers (2014).

During the measurements, the MW radiation effect on yeast is significant. GRUNDLER and co-workers $(1977,1982$, and 1988) observed that the growth rate of yeast S. cerevisiae could either be increased with up to $15 \%$ or decreased by $29 \%$ by MW irradiation within

\footnotetext{
* To whom correspondence should be addressed.

Phone:+36-96-566732; fax: +36-96-566641; e-mail: lakatose@mtk.nyme.hu
} 
41.8-42.0 GHz range. Significant MW effect on synchronization of $S$. carlsbergensis yeast cells were observed by Golant and co-workers (1994). Exposure to MW radiation at 30 $\mu \mathrm{W} \mathrm{cm}{ }^{-2}$ and $46 \mathrm{GHz}$ induced synchronization as measured by cell density and bud formation. Authors assumed that MW radiation activated cell-to-cell interaction resulting in the observed synchronization. BESZÉDES and co-workers $(2011,2014)$ determined that applying MW pretreatment, the volume of produced biogas from dairy and meat industry sludge was 19 times and 1.2 times higher, respectively, than that of obtained from raw sludge. Based on these studies, the positive potential of MW pre-treatment on grape must fermentation process was proved.

The aim of our experiments was the verification of the non-thermal effect of MW during grape must fermentation process.

\section{Materials and methods}

In our study, grape must (from local vineyard) fermentation process was measured. The experiments were performed with two series of measurements. In the first experimental set (2010) the fermentation of four samples were compared. In the case of the control sample no treatment was used. Yeast (S. cerevisiae, IOC B 2000 active dried yeast) was added to the second sample. The third sample was treated with MW $2.45 \mathrm{GHz}\left(50 \mathrm{~W}, 45 \mathrm{~min}, 32^{\circ} \mathrm{C}\right.$, MARS5 MW Digestion System). In the case of the fourth sample a combined treatment (yeast $+\mathrm{MW}$ ) was applied.

During the experiments the alcohol content was determined by the standard Malliganddevice with an accuracy of $\pm 0.2 \%$, V/V (ThÉNARD, 1875; Hungarian StANDARD, 1982), the sugar content of must was measured by NIR method using spectrophotometer type U-2910 Hitachi (Novales et al., 2009), and acidity by titration (OIV, 2009). Moreover, we investigated the energetic aspect of MW oven and hot plate with Energy Logger 4000 power-meter (Conrad), with three repetitions. The initial sugar content was $179.2 \mathrm{~g} \mathrm{l}^{-1}$.

In the second measurement series (2011) fermentation was compared applying six different treatments: (i) no treatment on control samples; (ii) hot plate heated ( $630 \mathrm{~W}, 45 \mathrm{~min}$, $32{ }^{\circ} \mathrm{C}$, YELLOW line, MST basic C); (iii) microwave-treated (50 W, $45 \mathrm{~min}, 32^{\circ} \mathrm{C}$ ); (iv) yeast supplementation (S. cerevisiae); (v) yeast inoculation while hot plate heated $\left(32^{\circ} \mathrm{C}\right)$; and (vi) microwave treatment and yeast supplementation. The quantity of simultaneously treated sample was $525 \mathrm{ml}$. Due to the design of microwave resonator, the penetration depth was $100 \%$. During the MW treatments the temperature change was detected with fibre optic temperature sensor (Probe, RTP-300Plus). After treatments, the must fermentation was carried out at $15-16{ }^{\circ} \mathrm{C}$ (Minifors S-000113794) in these experiments.

The results were evaluated with MS Office Excel 2010 and TableCurve 2D. During the statistical analysis, ANOVA and Student's $t$-test were used. The results shown in Tables 3 and 4 were evaluated by ranking method (related rank numbers), where the same data received the same rank values.

\section{Results and discussion}

Based on references (e.g. SHU-WeI et al., 2014), our results support what we expected, that the low power MW radiation has beneficial effect on yeast growth, so on the fermentation, too. The difference between untreated and treated samples was already seen at the beginning 
of the fermentation process. The sugar content of the control samples was decreased at a slower rate compared to the treated ones. Based on these results, it can be stated that fermentation is significantly influenced by the treatments.

Figure 1 shows that samples treated with yeast $+\mathrm{MW}$ supplementation reached the lowest value of sugar content on the $16^{\text {th }}$ day of fermentation. In the sample having only yeast supplementation, the sugar content decreased faster than the control. The yeast inoculated sample reached the minimum value on the $20^{\text {th }}$ day of fermentation, while in the MW treated sample this phenomenon occurred only on the $24^{\text {th }}$ day. The control sample reached the minimum value of sugar content $\left(39 \mathrm{~g}^{-1}\right)$ on the $28^{\text {th }}$ day of fermentation (end point).

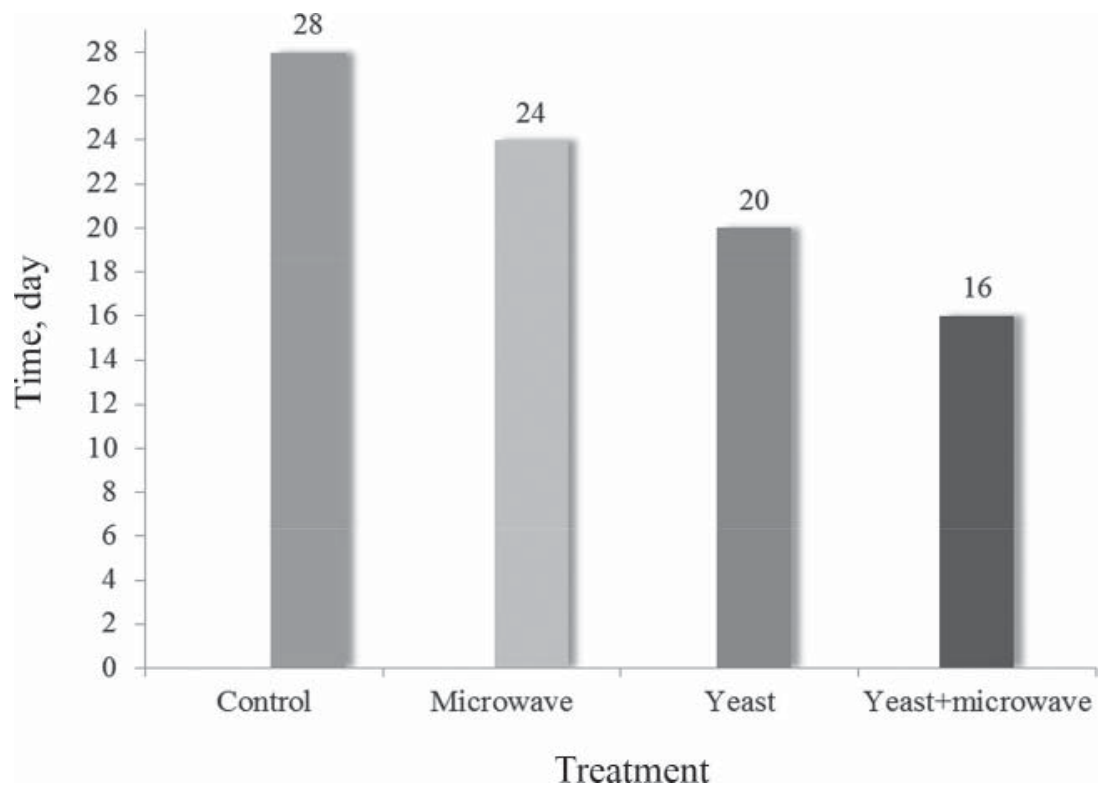

Fig. 1. Achieving final sugar content $\left(39 \mathrm{~g}^{-1}\right)$ during the fermentation due to different treatments shown in days (2010)

The alcohol content (Fig. 2) of the control samples increased slower than in treated samples. It gained its alcohol content $(11.6 \%)$ only at the end of the fermentation process.

Samples treated with yeast $+\mathrm{MW}$ and inoculated only with yeast samples reached the highest alcohol content $\left(12.6 \%\right.$ and $12.2 \%$, respectively) on the $20^{\text {th }}$ day of fermentation, which implies that the treatment significantly influenced the speed of fermentation.

The yeast $+\mathrm{MW}$ treated sample achieved the highest alcohol content between the 24 and 28 days of fermentation (12.1-12.2\%). 


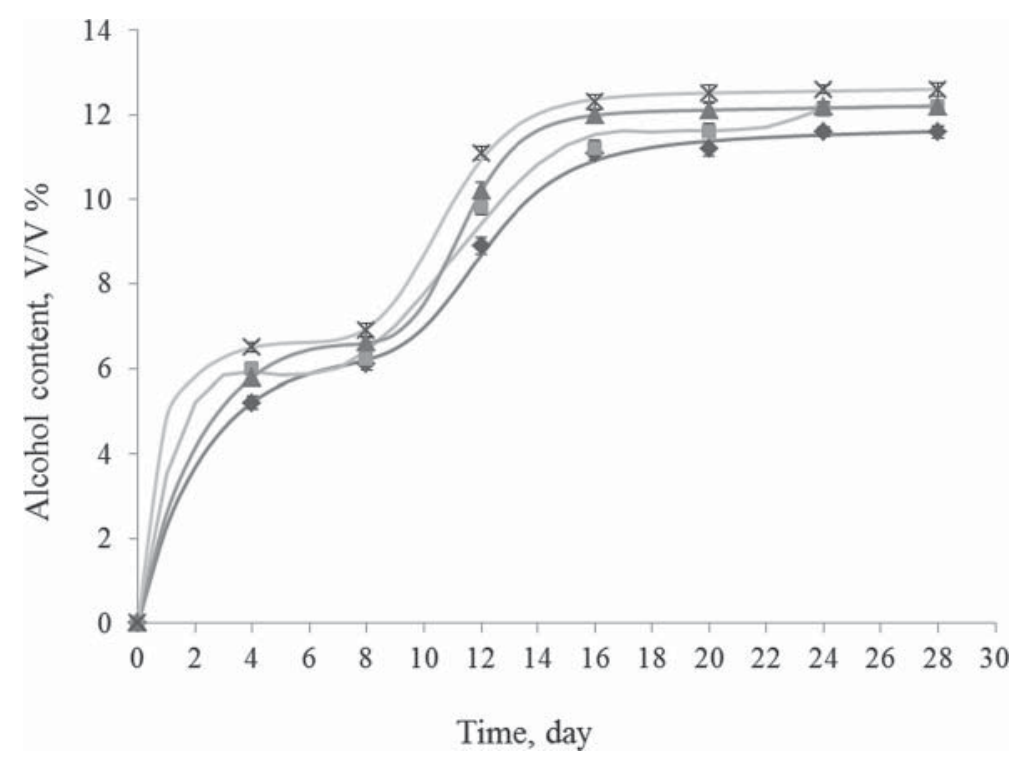

Fig. 2. Changes of the alcohol content of the must during the fermentation of samples : control; $\longrightarrow$ - microwave treated; $\longrightarrow$ : yeast treated; $\multimap$ : yeast and microwave treated (2010)

At the beginning of fermentation, acidity increased for a while and then decreased (Table 1), as stated in other studies, too (KálLAY, 2010).

Table 1. Change of acidity $\left(\mathrm{g}^{-1}\right)$ of the must during the fermentation of the control, yeast inoculated, microwavetreated, and microwave and yeast treated samples

\begin{tabular}{llllllll}
\hline Treatment & $4^{\text {th }}$ Day & $8^{\text {th }}$ Day & $12^{\text {th }}$ Day & $16^{\text {th }}$ Day & $20^{\text {th }}$ Day & $24^{\text {th }}$ Day & $28^{\text {th }}$ Day \\
\hline Control & $5.1 \pm 0.03$ & $6.1 \pm 0.02$ & $6.0 \pm 0.03$ & $6.3 \pm 0.03$ & $6.3 \pm 0.06$ & $6.3 \pm 0.06$ & $6.25 \pm 0.04$ \\
Yeast & $5.5 \pm 0.02$ & $6.2 \pm 0.03$ & $6.1 \pm 0.03$ & $5.6 \pm 0.06$ & $5.5 \pm 0.06$ & $5.55 \pm 0.06$ & $5.45 \pm 0.03$ \\
Microwave & $5.4 \pm 0.02$ & $6.2 \pm 0.03$ & $6.6 \pm 0.03$ & $6.4 \pm 0.03$ & $6.4 \pm 0.06$ & $6.4 \pm 0.02$ & $6.15 \pm 0.02$ \\
$\begin{array}{l}\text { Microwave }+ \\
\text { yeast }\end{array}$ & $5.8 \pm 0.02$ & $6.1 \pm 0.03$ & $5.9 \pm 0.03$ & $5.6 \pm 0.06$ & $5.6 \pm 0.05$ & $5.45 \pm 0.05$ & $5.2 \pm 0.02$ \\
\hline
\end{tabular}

In the second replications (2011) we also carried out hot plate treatments, where the fermentation process advanced like in the first series of experiments. In the case of a second measurement series, similar results were experienced with the sugar content as in the first measurements (Fig. 3). The combination treated (yeast $+\mathrm{MW}$ ) sample reached the lowest value of sugar content the earliest on the $14^{\text {th }}$ day of fermentation. It can be noted that yeast treated and hot plate-heated samples reached the lowest sugar content on the $16^{\text {th }}$ day of fermentation (23 days total fermentation), while the remaining samples reached this more slowly. 


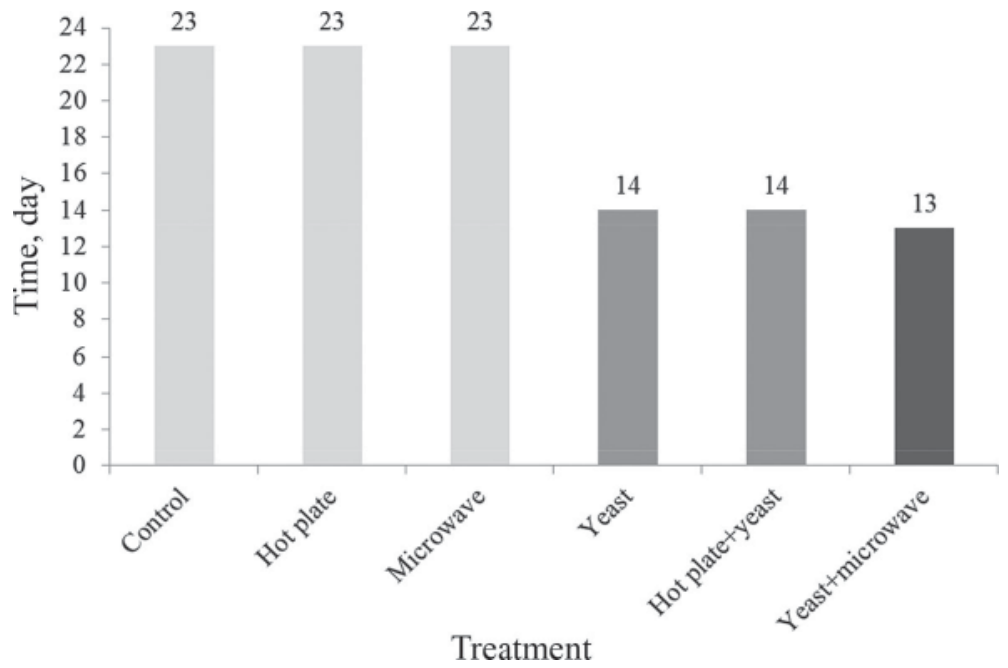

Fig. 3. Achieving final sugar content $\left(39 \mathrm{~g} \mathrm{l}^{-1}\right)$ during the fermentation due to different treatments shown in days (2011)

Distinctly, fermentation started on the $2^{\text {nd }}$ day of measurement. As shown in Figure 4, there was a significant difference between the alcohol content of the control sample $(0.4 \%)$ and the treated samples ( 1 to $3.1 \%$ ).

The alcohol contents of the combined treated samples reached the highest level $(10.4 \%$ and $10.2 \%$ ) on the $14^{\text {th }}$ day of fermentation. These treatments also influence the speed of fermentation. The alcohol content of the must samples treated only with yeast inoculation or hot plate reached the highest level on the $18^{\text {th }}$ day of fermentation $(10 \%$ and $9.8 \%$, respectively).

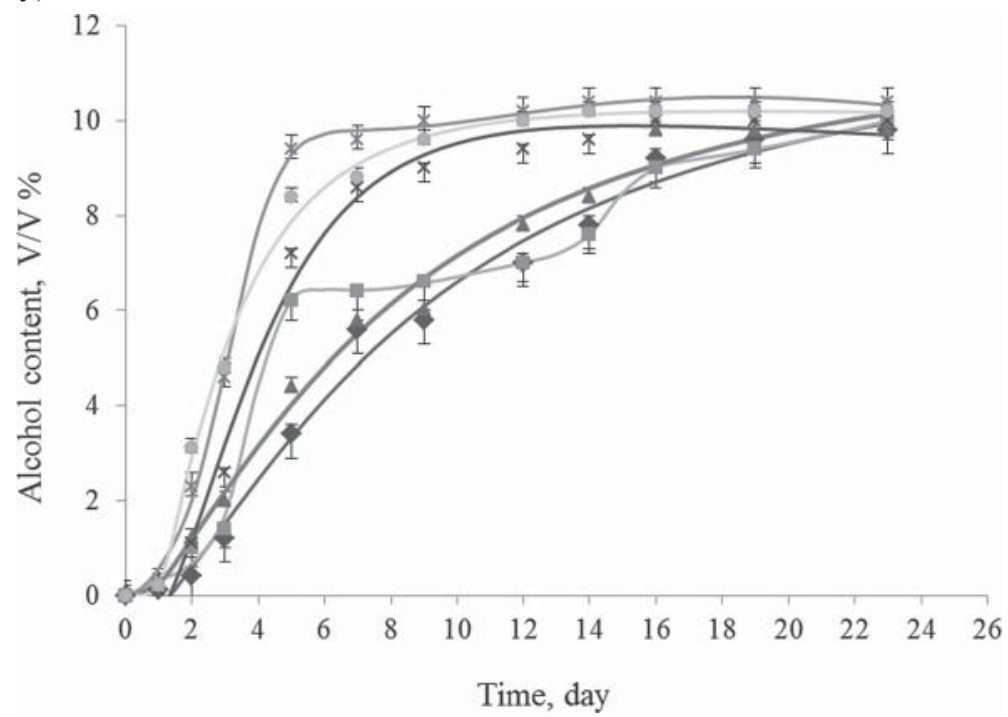

Fig. 4. Change of the alcohol content of the must during the fermentation of the samples : control; $\longrightarrow$ - hot plate treated; $\longrightarrow-$ : microwave-treated; $\longrightarrow$ : yeast inoculated; $\rightarrow$ : hot plate+yeast; - : microwave and yeast treated (2011) 
Concerning acidity (Table $2 \mathrm{a}-\mathrm{b}$ ), it can be concluded that the combination treated samples have the largest acidity. The acidity change is not as uniform as the sugar and alcohol content change, because during fermentation yeast consumes some acids (tartaric acid, malic acid), while new ones also form (succinic acid, lactic acid) (EPERJEsI et al., 1998).

It can be stated that the average acidity difference between Day 0 (must) and Day 23 (wine) was $23.31 \%$. The difference between acidity was found to be $28.44 \%$.

Table 2a. $-b$. Change of acidity $\left(\mathrm{g}^{-1}\right)$ of the must during the fermentation of the control, hot plate heated, the microwave-treated, yeast inoculated, hot plate+yeast, and with microwave and yeast treated samples a

\begin{tabular}{|c|c|c|c|c|c|c|}
\hline Treatment & $0^{\text {th }}$ Day & $1^{\text {th }}$ Day & $2^{\text {th }}$ Day & $3^{\text {th }}$ Day & $5^{\text {th }}$ Day & $7^{\text {th }}$ Day \\
\hline Control & \multirow{6}{*}{$4.3 \pm 0.03$} & $4.55 \pm 0.02$ & $4.33 \pm 0.02$ & $4.97 \pm 0.04$ & $5.45 \pm 0.04$ & $5.52 \pm 0.02$ \\
\hline Hot plate & & $4.48 \pm 0.02$ & $4.72 \pm 0.06$ & $5.38 \pm 0.02$ & $5.62 \pm 0.03$ & $5.35 \pm 0.02$ \\
\hline Microwave & & $4.45 \pm 0.06$ & $5.13 \pm 0.04$ & $5.63 \pm 0.03$ & $6 \pm 0.02$ & $5.98 \pm 0.04$ \\
\hline Yeast & & $4.47 \pm 0.06$ & $4.87 \pm 0.06$ & $5.8 \pm 0.04$ & $5.62 \pm 0.04$ & $5.37 \pm 0.03$ \\
\hline Hot plate+yeast & & $4.22 \pm 0.02$ & $5.28 \pm 0.02$ & $5.97 \pm 0.06$ & $6.12 \pm 0.03$ & $5.4 \pm 0.06$ \\
\hline Microwave+yeast & & $4.72 \pm 0.04$ & $5.53 \pm 0.02$ & $5.75 \pm 0.03$ & $5.73 \pm 0.06$ & $5.58 \pm 0.04$ \\
\hline
\end{tabular}

$b$.

\begin{tabular}{lllllll}
\hline Treatment & $9^{\text {th }}$ Day & $12^{\text {th }}$ Day & $14^{\text {th }}$ Day & $16^{\text {th }}$ Day & $19^{\text {th }}$ Day & $23^{\text {th }}$ Day \\
\hline Control & $5.47 \pm 0.04$ & $5.37 \pm 0.02$ & $5.39 \pm 0.02$ & $5.37 \pm 0.03$ & $5.73 \pm 0.04$ & $5.63 \pm 0.04$ \\
Hot plate & $5.72 \pm 0.02$ & $5.82 \pm 0.04$ & $5.77 \pm 0.02$ & $5.82 \pm 0.02$ & $5.88 \pm 0.03$ & $5.62 \pm 0.03$ \\
Microwave & $5.78 \pm 0.06$ & $5.78 \pm 0.03$ & $5.68 \pm 0.04$ & $5.78 \pm 0.06$ & $5.72 \pm 0.06$ & $5.82 \pm 0.02$ \\
Yeast & $5.05 \pm 0.04$ & $5.35 \pm 0.04$ & $5.05 \pm 0.04$ & $5.35 \pm 0.03$ & $5.28 \pm 0.06$ & $5.22 \pm 0.04$ \\
Hot plate+yeast & $5.52 \pm 0.02$ & $5.63 \pm 0.02$ & $5.38 \pm 0.04$ & $5.63 \pm 0.04$ & $5.22 \pm 0.04$ & $5.52 \pm 0.03$ \\
Microwave+yeast & $5.35 \pm 0.02$ & $5.38 \pm 0.04$ & $5.38 \pm 0.02$ & $5.38 \pm 0.03$ & $5.17 \pm 0.03$ & $5.35 \pm 0.06$ \\
\hline
\end{tabular}

Tables 3 and 4 show that the highest influence was found in case of yeast + MW treated samples, yeast inoculated samples were in the second place.

Table 3. The effect of treatments on different parameters

\begin{tabular}{lcccc}
\hline Treatment & $\begin{array}{c}\text { Sugar content } \\
\left(7^{\text {th }} \text { day }\right)\end{array}$ & $\begin{array}{c}\text { Alcohol formation } \\
\text { rate }\end{array}$ & $\begin{array}{c}\text { Final alcohol } \\
\text { content }\end{array}$ & $\begin{array}{c}\text { Summ. } \\
\text { total influence }\end{array}$ \\
\hline Control & 1 & 1 & 1 & 3 \\
Microwaves & 2 & 2 & 3 & 7 \\
Yeast & 3 & 3 & 2 & 8 \\
Yeast and & 4 & 4 & 4 & 12 \\
microwave & & 4 &
\end{tabular}

(Rating between 1-4; 1: minimum impact; 4 : maximum impact) 
Table 4. The effect of treatments on different parameters

\begin{tabular}{lcccc}
\hline & $\begin{array}{c}\text { Sugar content } \\
\left(7^{\text {th }} \text { day }\right)\end{array}$ & Alcohol formation rate & Final alcohol content & $\begin{array}{c}\text { Summ. } \\
\text { total influence }\end{array}$ \\
\hline Control & 2 & 1 & 3 & 6 \\
Hot plate & 4 & 3 & 3 & 10 \\
Microwaves & 3 & 2 & 1 & 6 \\
Yeast & 6 & 4 & 3 & 13 \\
Hot plate+yeast & 1 & 5 & 5 & 11 \\
Yeast and & 5 & 6 & 6 & 18 \\
microwave & & &
\end{tabular}

(Rating between 1-6; 1: minimum impact; 6: maximum impact)

During the experiments we analysed the energetic aspects, too. The duration of treatment was $45 \mathrm{~min}$. The energy consumption used for MW heating was $173.52 \mathrm{~kJ}$ (without energy use of fan, lights, and rotating disc), at the same time the hot plate heating used $204.14 \mathrm{~kJ}$ energy. Consequently, the energy consumption of MW heating compared to hot plate energy consumption is almost $20 \%$ less under lab conditions.

\section{Conclusions}

In the measurement series carried out in 2010 (control, yeast inoculated, MW treated, yeast + MW combined samples) and 2011 (control, yeast inoculated, hot plate heated, MW treated, yeast+MW, and hot plate+yeast combined samples) gave similar results of fermentation process. The sugar content of the treated samples rapidly decreased compared to the control sample and the fermentation time was shorter by $40 \%$ in the fastest case. These results can be explained by the yeast inoculation and the MW treatment.

The statistical analysis showed no significant difference $(\mathrm{P}=5 \%)$ between any samples in the first series. In this case, the non-thermal effect of MW is not present or has no effect on the results. The second series of measurements did not show significant difference between each sample, regarding the alcohol content during the whole fermentation. In the first third of fermentation there was verifiable difference $(\mathrm{P}=5 \%)$ between the samples.

It was concluded that a short-term heat treatment prior to fermentation up to $32{ }^{\circ} \mathrm{C}$ influences the parameters of the fermentation using yeast in a positive way. The fermentation time was reduced, while the alcohol yield increased.

In aspect of energetic, it can be stated that in case of hot plate treatment, 5.4 times more energy is needed than for MW treatment, however the fermentation time increased by $14.2 \%$ in case of MW treatment compared to hot plate heated treatments (Fig. 4).

In the fermentation period (September-October), grape must has to be cooled in order to keep the temperature at $16^{\circ} \mathrm{C}$. By shortening the fermentation time, cooling energy can be also reduced. On the other hand, this means that using MW treatment of grape must also results in energy saving compared to conventional hot plate heating, while increasing the fermentation capacity by about $30 \%$. 
We wish to thank to "OTKA" (Hungarian Scientific Research Fund), "Bolyai János" Research Scholarship, TÁMOP-4.2.2.A-11/1/KONV and GOP-1.1.1-11.-2012-0157 projects.

\section{References}

BEszÉDES, S. (2014): Szennyvíziszapok biológiai lebonthatóságának növelése mikrohullámú elökezeléssel. (Improvement of biodegradability of sludge by microwave pre-treatment). PhD thesis, University of Szeged, 129 pages.

Beszédes, S., LÁszló, Zs., Horváth, H-Zs., Szabó, G. \& Hodúr, C. (2011): Comparison of the effects of microwave irradiation with different intensities on the biodegradability of sludge from the dairy- and meat-industry. Bioresource Technol., 102(2), 814-821.

Biacs, P., Szabó, G., Szendrö, P. \& VÉHA, A. (2010): Élelmiszer-technológia mérnököknek (Food-Technology for Engineers), SZTE Mérnöki Kar, Szeged, pp. 345-385.

Calado, C.R.C., Taipa, M.A., Cabral, J.M.S. \& FonseCA, L.P. (2002): Optimisation of culture conditions and characterization of cutinose produced by recombinant Saccharomyces cerevisiae. Enzyme Microb. Tech., 31, $161-170$.

Dreyfuss, M.S. \& Chipley, J.R. (1980): Comparison of effects of sublethal microwave radiation and conventional heating on the metabolic activity of Staphylococcus aureus. Appl. Environ. Microb., 39(1), 13-16.

Eperjesi, I., Kállay, M. \& Magyar, I. (1998): Borászat (Winery). Mezőgazda Kiadó, Budapest, 547 pages.

Farkas, G., Rezessy-Szabó, J.M., ZÁkÁny, F. \& Hoschke, Á. (2005): Interaction of Saccharomyces and nonSaccharomyces yeast strains in an alcoholic fermentation process. Acta Alimentaria, 34, 81-90.

Géczi, G., Korzenszky, P., Horváth, M. \& Molnár, E. (2013): Heat treatments versus fermentation. Animal Welfare, Ethology and Housing Systems, 9(3), 448-454.

Golant, M.B., Kuznetsov, A.P. \& Bozhanova, T.P. (1994): The mechanism of synchronizing yeast cell cultures with EHF radiation (in Russian), Biofizika, 39, 490-495.

Grundler, W., Keilman, F. \& Froehlich, H. (1977): Resonance growth rate response of yeast cells irradiated by weak microwaves. Physics Lett. A., 62, 463-466.

Grundler, W., Keilman, F., Putterlik, V. \& Strube, D. (1982): Resonant-like dependence of yeast growth rate on microwave frequencies. Brit. J. Cancer, 45, 206-208.

Grundler, W., Jentzsch, U., Keilman, F. \& Putterlik, V. (1988): Resonance cellular effects of low intensity microwave. -in: Frolich, H. (Ed.), Biological coherence and response to external stimuli. Springer-Verlag, Berlin, pp. 65-85.

Hungarian Standard (1982): Borok szesztartalmának meghatározása Malligand-készülékkel (Determination of alcohol content of wines with Malligand-device). MSZ 9457:1982.

Kállay, M. (2010): Borászati kémia. (Oenological chemistry). Mezőgazda Kiadó, Budapest, 206 pages.

KorzenszKy, P. \& MolnÁr, E. (2014a): Must tartósításának vizsgálata (Examination of preservation of grape must). Konzervújság, LXII.(1), 27-31.

KorZENSZKy, P. \& MolnÁR, E. (2014b): Examination of heat treatments at preservation of grape must. Potravinarstvo, $8(1), 33-37$.

Kothari, V., Patadia, M. \& Trivedi N. (2011): Microwave sterilized media supports better microbial growth than autoclaved media. Res. Biotechnology. 2(5), 63-75.

Novales, J-F., López, M-I., SÁnchez, M-T. \& Morales, J. (2009): Shortwave-near infrared spectroscopy for determination of reducing sugar content during grape ripening, winemaking, and aging of white and red wines. Food Res. Int., 42, 285-291.

OIV (2009): Total acidity, revised by 377/2009, OIV-MA-AS313-01

Pickering, G.J., Heatherbell, D.A. \& Barnes, M.F. (1998): Optimising glucose conversion in the production of reduced alcohol wine using glucose oxidase. Food Res. Int., 31, 685-692.

Pretorius, I.S. (2000): Tailoring wine yeast for the next millennium: Novel approaches to the ancient art of winemaking. Yeast, 16, 675-729.

Rai, S., Singh, U.P., Mishra, G.D., Singh, S.P. \& Samarketu, S.P. (1994a): Effect of water's microwave power density memory on fungal spore germination. Electro Magnetobiol. 13, 247-252.

Rai, S., Singh, U.P., Mishra, G.D., Singh, S.P. \& Samarketu, S.P. (1994b): Additional evidence of stable EMFinduced changes in water revealed by fungal spore germination. Electro Magnetobiol. 13, 253-259. 
Sablayrolles, J.M. (2009): Control of alcoholic fermentation in wine making: Current situation and prospect. Food Res. Int., 42, 418-424.

Shu-Wei, Z., Qi-Lin, H. \& Si-Ming, Z. (2014): Effects of microwave irradiation dose and time on yeast ZSM-001 growth and cell membrane permeability. Food Control, 46, 360-367.

ThÉNARD, L.J. (1875): Rapport sur un appareil de M. Malligand, pour titrer l'alcool des vins. Compt. rend., 80, 1114. Trivedi, N., Patadia, M. \& Kothari, V. (2011): Biological applications of microwaves. Int. J. Life Sci. Tech., 4(6), $37-46$.

Wayland, J.R., Brannen, J.P. \& Morris, M.E. (1977): On the interdependence of thermal and electromagnetic effects in the response of Bacillus subtilis spores to microwave exposure. Radiat. Res., 71, 251-258.

Welt, B., Tong, C., Rossen, J. \& Lund, D. (1994): Effect of microwave radiation on inactivation of Clostridium sporogenes (PA 3679) spores. Appl. Environ. Microb., 60, 482-488. 